\title{
ALLOCATION OF RISK IN THE CONSTRUCTION INDUSTRY: THE NONPROFESSIONAL OWNER AND HIS CONSTRUCTION MANAGER
}

\author{
I \\ INTRODUCTION
}

It has been said that construction is a form of legalized gambling.' Annually, thousands of architects, contractors, and subcontractors declare bankruptcy ${ }^{2}$ while projects are abandoned because owners lack the funds needed for completion. The high-risk nature of the construction industry is attributable to various factors. First, an error in construction involving relatively inexpensive materials or workmanship may require remedial work far more expensive than that first performed. When such an error is not discovered until late in the construction process, the cost of repair or replacement is likely to be disproportionately high. ${ }^{3}$ Second, the interdependency of the many trades and professions involved in a project means that delays or problems in one aspect of the process may cause substantial loss to a sizeable number of these parties. Third, the high number of unforeseeable events which may intervene to delay construction increases the risk involved. In addition to the obvious problem of inclement weather, the risk of negligent error by a contractor or other party always exists. The risk of nonnegligent error-that which could not be avoided even with the exercise of due care-is also present. ${ }^{4}$

The owner has traditionally borne the risk of loss since he is the one who initiates the entire construction process. ${ }^{5}$ Given the magnitude of the risk involved, the owner is continually seeking to limit the risk to which he is exposed. Risk-

Copyright (C) 1983 by Law and Contemporary Problems

l. Sinnott, Insurance for Construction Projects, in Real Estate Construction Current Problems 175, 175 (PLI ed. 1973).

2. Dun \& Bradstreet reports that 2,710 contracting firms failed in 1981 . In the first seven months of 1982, 2,206 contractors declared bankruptcy. Failures Hit 50 Year High, Eng'G News-Record, Sept. 9, 1982 , at 68 .

3. For example, an improper window sealant was used in building San Francisco's Embarcadero Center. The ineffectiveness of the sealant was not discovered until construction was almost completed at which time replacement of the sealant cost approximately a quarter of a million dollars. Habenicht \& Howlett v. Jones-Allen-Dillingham, No. 1 Civ. 46449, slip op. at 8 (Cal. Ct. App. Dec. 29, 1981).

4. Although the sealant in the Embarcadero Center was apparently recommended by the manufacturer for the intended use, approved by the architect, and applied according to instructions, the sealant was ineffective. Id. at 5, 9. Although the purchaser would have had a warranty action against the manufacturer, none of the parties involved in the lawsuit was at fault.

5. See Goldberg, The Owner's Duty to Coordinate Multi-Prime Constnuction Contractors, A Condition of Cooperaiion, 28 EMORY L.J. 377 (1979). 
spreading methods which benefit parties other than the owner are generally accepted; payment bonds and errors and omissions insurance for design professionals are two such methods. Some other risk-spreading methods are limited in their availability. For example, "no damages for delay" clauses are valid with respect to occurrences beyond the contractor's control, such as weather, but are not valid with respect to the owner's active interference with the progress of the work. ${ }^{6}$ No mechanism has been developed for allocating the risk of nonnegligent error. ${ }^{7}$

The owner's desire to limit risk does not exist in a vacuum, however. The owner generally has four other major concerns in a construction project: (1) that the end product be a well-built structure of high quality, (2) that the project be completed on time, (3) that the project be constructed at the contract price, and (4) that the property be protected from liens which hinder the owner's ability to raise capital and can even result in loss of the property.

The emergence of construction management in the 1960 's ${ }^{8}$ presents the owner with one method which seems to achieve all his objectives. The construction manager (CM) brings to the process the expertise necessary to ensure quality while being particularly sensitive to the owner's desire to limit the time for and cost of completion. ${ }^{9}$ By delegating to the CM the duty to schedule and coordinate work, the owner may attempt to shift the risk in those areas to the CM. However, while courts have reacted in varied ways to the legal implications of construction management, they have generally been reluctant to allow the risks of construction or the duty to coordinate to be shifted from the owner to the CM. Whether this absence of risk-shifting is consonant with the philosophy of construction management and the public policy concerning allocation of risk is the subject of this article. $^{10}$

This article takes the viewpoint of the owner, since he is the party most concerned with allocation of risk. However, "owners" as a whole have too many divergent characteristics to be considered as a single category. The most important difference among owners is the frequency with which they build. The public owner who builds frequently falls into a category separate from one including the private or public owner who builds only occasionally. The amount of construction with which the owners are involved makes these categories different in two important respects: degree of expertise and degree of influence.

When the owner is the United States Government, for example, a great deal of expertise is available. The Public Building Service of the General Services Administration (GSA PBS) has a large staff with numerous years of construction experience. Those owners with only occasional experience with construction, however,

6. See, e.g., John E. Green Plumbing \& Heating Co. v. Turner Constr. Co., 500 F. Supp. 910 (E.D. Mich. 1980).

7. See infra text accompanying notes 103-04.

8. Sneed, The Construction Manager's Liability, in Construction Litigation 317, 317 (PLI ed. 1981).

9. Id. at 325-26.

10. While the role of the CM takes various forms (see id. at 329-35), in this article the CM is envisioned as a prime contractor who serves not as an agent of the owner but as an independent manager and coordinator of the construction process. 
have little opportunity to develop expertise in the field. Indeed, a substantial portion of the construction in this country is done at the behest of owners who are not regularly involved in sizeable building projects. ${ }^{11}$ This large group might be called "private owners" except that most state and local governments are similarly situated with respect to their lack of expertise. Thus, for the purposes of this article, private owners and state and local governments will be referred to as "nonprofessional owners."

Another distinguishing characteristic of the nonprofessional owner is his lack of representation by trade organizations. Contractors are represented by the National Constructors Organization, the Associated Building Contractors, and the Associated General Contractors (AGC). Design professionals are represented by the National Society of Professional Engineers, the American Society of Civil Engineers, and the American Institute of Architects (AIA). Subcontractors are represented by the American Subcontractors Association, the Specialty Trade Association of America, and various other industry groups. This representation provides an influential voice in the passage of legislation beneficial to that particular group. Moreover, these and other actors in the construction field often have their own standard form contracts. The powerful AIA has developed a set of documents, as has the AGC. The GSA PBS also has its own set of contracts more favorable to the owner. Since the duties and liabilities of the parties are determined by the terms of their contracts, the existence of such documents has widespread implications. The nonprofessional owner has neither a united lobbying voice nor standard form contracts to protect his interests. Therefore, this article takes the viewpoint of the nonprofessional owner.

\section{II}

\section{Barriers to OWner's Delegation of the Duty to Coordinate}

A. Historical Origins and the Liability of the Owner Today Under the AIA, AGC, and GSA PBS Contracts

The owner's duty to coordinate originated during the Industrial Revolution in England in the 1830 's. ${ }^{12}$ In one of the earliest cases, ${ }^{13}$ an owner was held to have unjustly refused payment to a contractor where the delay in completion was the fault of another contractor. Within a few years, this idea had evolved into a separate cause of action by the delayed contractor against the owner for delays attributable to another contractor. ${ }^{14}$ The root of the decisions was that site access, to be furnished by the owner, was a prerequisite for the contractor's completion in the time established in the contract. ${ }^{15}$ From this predicate the courts derived the prin-

11. In $1981, \$ 237,087,000,000$ worth of new construction was put in place. Of that amount, $\$ 59,747,000,000$ was private nonresidential. The public sector accounted for $\$ 53,536,000,000$. BUREAU OF the Census, U.S. Dep'T OF Commerce, Construction Reports-VAlue of NeW Construction Put in Place 3 (Apr. 1982).

12. Goldberg, supra note 5 , at 379 .

13. Holme v. Guppy, 150 Eng. Rep. 1195 (Ex. 1838).

14. See Allamon v. Mayor of Albany, 43 Barb. 33 (N.Y. App. Div. 1864); See v. Partridge, 9 N.Y. Super. Ct. Rep. (2 Duer) 463 (1853).

15. Goldberg, supra note 5, at 379. Current standard form contracts grant the CM damages for delays 
ciple that orderly access of each of several succeeding trade contractors to the site requires coordination and that the party most aware of each contractor's scheduled commencement and completion dates and access needs-the owner-should be the party responsible for coordination. ${ }^{16}$

The owner remains liable for damages for delay in scheduling and coordination even today under the AIA, AGC, and GSA PBS standard form contracts, and despite the presence of a CM. ${ }^{17}$ The AIA construction management contract is the one most widely used in the industry. ${ }^{18}$ It requires the CM to schedule and coordinate the work of the prime contractors. ${ }^{19}$ However, the owner retains the right to use prime contracts, the residual duty to coordinate the work of the primes if the CM has not done so, and the power to stop any noncomplying work and complete the contract himself. ${ }^{20}$ While the CM is held only to a due diligence standard in the performance of his contract, the owner is ultimately responsible for coordination. ${ }^{21}$

Under the AGC construction management contract, the CM develops a schedule, ${ }^{22}$ coordinates contract documents (without assuming any responsibility for design), ${ }^{23}$ and monitors and coordinates the contractors' work. ${ }^{24}$ If a trade contractor's work is not adequate, the CM will recommend a course of action to the owner, ${ }^{25}$ but the CM has no sanction authority of his own. The power to terminate a defaulting contractor remains with the owner. ${ }^{26}$ The CM is thus only an agent for the owner with respect to coordination and will probably not be held liable for scheduling problems. The AGC contract does, however, provide for the

caused by owners. See Associated General Contractors, Standard Form of Agreement Between Owners and Construction Managers (Guaranteed Maximum Price Option), Doc. 8, art. 6 (June 1977) [hereinafter cited as AGC 1977 GMP Agreement], reprinted in Businessman's GuIDE TO CONSTRUCTION 248 [hereinafter cited as BUSINESSMAN's GUIDE].

16. See, e.g., Gasperini Excavating Co. v. Pennsylvania Turnpike Comm'n, 409 Pa. 465, 187 A.2d 157 (1963).

17. Courts will even sometimes look closely at what the term "contractor" means to see if, in fact, this party is nothing more than an agent for the owner. In Everette v. Alyeska Pipeline Serv. Co., 614 P.2d 1341 (Alaska 1980), the pipeline company's defense against the claim of an injured worker was that it was a contractor which had itself hired the subcontractors. The court, however, looked through the form to the substance of the relationship, finding that Alyeska acted as an "integral part" of the oil companies and was created by them for the sole purpose of coordinating the construction of the Alaskan pipeline. Id. at 1346 . Alyeska's only job was to secure contracts of outsiders and supervise, not "to execute pipeline construction." Id.

18. American Institute of Architects, Standard Form of Agreement Between Owner and Construction Manager, Doc. B801 (1980). [hereinafter cited as AIA CM Agreement]; American Institute of Architects, Standard Form of Agreement Between Owner and Construction Manager, Doc. B801 (1973), reprinted in Businessman's Guide, supra note 15, at 238. See generally Sweet, The Archilect Profession Respond's to Construction Management and Design-Build: The Spotlight on AIA Documents, LAW \& CONTEMP. ProBs., Winter 1983, at 69 , at text accompanying nn.1-5.

19. AIA CM Agreement, supra note 18, arts. 1.2.2-1.2.2.3.

20. American Institute of Architects, General Conditions of the Contract for Construction, Doc. A201/CM, art. 6.1 .3 (constr. management ed. June 1980).

21. Sneed, supra note 8 , at 365 .

22. AGC 1977 GMP Agreement, supra note 15, art. 2.1.2.

23. Id. art. 2.1.4.

24. Id. arts. 2.2.1-2.2.1.6.

25. Id. art. 2.2.1.6.

26. Article 2.2.1.6 requires the CM to "[r]ecommend courses of action to the Owner when requirements of a Trade Contract are not being met." Id. 
CM to guarantee a maximum price if desired by the owner. ${ }^{27}$ When the CM thereby assumes the entrepreneurial risk of the contract, he retains the authority to enforce the work schedule and to coordinate the contractor's work. ${ }^{28}$

Under the GSA PBS's construction management contract, the CM ensures that the construction will be completed on or before the scheduled completion date and as early as possible. ${ }^{29}$ He must also develop a comprehensive schedule for the project. ${ }^{30}$ However, the ultimate power to enforce the schedule remains with the GSA's contracting officer. ${ }^{31}$ Thus the CM is only an agent for the owner; the owner holds the ultimate responsibility for scheduling and coordination. It is notable that even the GSA PBS contract, which is written by an owner, provides the same result as the AIA and AGC contracts: The owner is ultimately liable for delays resulting from a breakdown in scheduling and coordination.

Pierce Associates v. United States ${ }^{32}$ illustrates that the courts of today also are reluctant to relieve the owner of liability. In that case, a structural prime contractor fell behind in the performance of his work. Despite receiving notification of the problem from the CM, the GSA PBS's contracting officer did nothing for more than five months. When sued by a mechanical prime who was delayed by the structural prime, the GSA PBS asserted that the mutual responsibility clause in each of the prime contracts required that the delayed contractor bring an action directly against the delaying contractor. The court sidestepped this argument by saying that regardless of whether the delayed prime had a cause of action directly against the delaying prime, the action against the GSA PBS was proper because of the agency's power to order a delaying contractor to increase shifts and workdays and to work overtime. Thus, Pierce stands for the proposition that, despite the inclusion of a mutual responsibility clause and many attempts by the CM to effect compliance, the owner must take affirmative action in a timely manner. ${ }^{33}$

Given the change in the nature of the owner today, however, the rationale behind the nineteenth century cases and recent ones such as Pierce may no longer be applicable to hold the owner to a nondelegable duty to coordinate. Today,

27. Id. art. 6.

28. See Conner, Contracting for Construction Management Services, LaW \& CoNTEMP. ProbS., Winter 1983, at 5, 13-16.

29. Public Building Service, General Service Administration Construction Management Contract (rev. ed. Apr. 15, 1975), reprinted in Public Building Service, General Service Administration, The GSA SyStem For Construction MANAGEMENT 23 (1977).

30. Id. art. 4 , at $7-12$.

31. Id. art. 14 , at 19 ; Sneed, supra note 8 , at 359-60.

32. 77-2 B.C.A. (CCH) \ 12,746 (1977).

33. While continuing to impose liability on the GSA as owner, the courts have not established the standards of conduct governing the duty to coordinate. The duty has been characterized as an obligation "to prevent interference with orderly and reasonable progress of a contractor's work by other contractors over whom the Government has control." L.L. Hall Constr. Co. v. United States, 379 F.2d 559, 564 (Ct. Cl. 1969). Another court has required "reasonable efforts." Paccon, Inc. v. United States, 399 F.2d 162, 170 (Ct. Cl. 1968). Nevertheless, authorities are split concerning whether an owner is required to terminate a defaulting contractor after all other steps have been taken, albeit unsuccessfully. Compare id. at 171 with Norelli \& Oliver Constr. Co. v. State, 30 A.D.2d 992, 294 N.Y.S.2d 35 (1968), affd, 32 N.Y.2d 809,289 N.E.2d 691, 345 N.Y.S.2d 556 (1973). Termination is an extreme remedy which the owner would prefer to avoid, since it may expose him to liability for delay damages to other contractors during the time it takes to identify and mobilize a successor. 
when complicated scheduling (often taking the form of the critical path method) is demanded, the tasks formerly undertaken by the owner are now performed by a specialist. Most often, the CM is this specialist.

When the first coordination cases described the duty as belonging to the owner, they were in fact ignoring the issue of fault and instead allocating the risk to the party who had the superior knowledge and control. ${ }^{34}$ Such a result also seemed equitable because it was the owner who had created the situation with its potential difficulties. ${ }^{35}$ Today, however, it is the CM who possesses both the superior knowledge and the ability to eliminate timing and site-access problems and to derive solutions for such problems through coordination; the owner, particularly the nonprofessional owner, clearly plays a background role. It follows that the rationale used by those early courts to hold the owner responsible for coordination can be applied today to impose on the CM, not the owner, the responsibility for coordination.

\section{B. Statutory Barriers ${ }^{36}$}

For the public nonprofessional owner, state statutes governing the award of contracts may present additional bars to reallocating the risk of construction in two ways. ${ }^{37}$ First, the statutes may preclude the nonprofessional owner from delegating the duty to coordinate. Second, the desirability of using construction management may be lessened when a public contract must be awarded to the lowest bidder.

The public bidding statutes governing the State of New York and its municipalities have been interpreted to forbid delegation of the duty to coordinate. Those statutes require that for construction projects of more than $\$ 50,000$, separate contracts must be awarded for various trades or segments of the work. ${ }^{38} \mathrm{~A}$ provision of a contract requiring the contractor for general construction to submit

34. Goldberg, supra note 5, at 382. See generally 6 A. Corbin, Corbin on Contracts $§ 1340$ (1962); 18 S. Williston, A Treatise on the LaW of Contracts $\$ 1932$, at 12 (3d ed. 1978).

35. See Goldberg, supra note 5 , at 382 .

36. This section is not intended to be an exhaustive survey of the states. Rather, its purpose is to highlight particular statutes which illustrate the relevant problems.

37. State licensing provisions may reduce the effectiveness of a CM even for private owners. For example, North Carolina defines "any person or firm or corporation who . . . undertakes to superintend or manage. . . the construction of any building . . . where the cost . . . is thirty thousand dollars $(\$ 30,000)$ or more" to be a "general contractor." N.C. GeN. STAT. § 87-1 (Supp. 1981). When an unlicensed party enters into such a contract, he cannot sue for breach or recover on a quasi-contractual theory. Bryan Builders Supply v. Midyette, 274 N.C. 264, 270, 273, 162 S.E.2d 507, 511, 512-13 (1968); Revis Sand \& Stone v. King, 49 N.C. App. 168, 171, 270 S.E.2d 580, 582 (1980).

While a misdemeanor penalty is also imposed on the unlicensed contractor, N.C. GEN. STAT. § 87-13 (1981), this party's loss of ability to enforce contracts has more serious implications for the construction process. When the owner does not contract directly with the primes, an unlicensed CM's inability to sue has the potential to wreak havoc with completion of and proper payment for work.

38. N.Y. GeN. MuN. LaW $\S 101$ (McKinney 1977) states in relevant part:

1. Every officer, board or agency of a political subdivision of any district therein, charged with the duty of preparing specifications or awarding or entering into contracts for the erection, construction, reconstruction or alteration of buildings, when the entire cost of such work shall exceed fifty thousand 
a work progress schedule was found to violate the statute. ${ }^{39}$ The court reasoned that in requiring a contractor to prepare a work schedule, the state shifted its duty of coordination without specific legislative authority to do so. ${ }^{40}$ The New York courts have, however, recognized that compelling the government body to enter into separate contracts while forcing that body to retain the duty of coordination is extremely inefficient:

The Court would like to observe that Section 135 of the State Finance Law, and any other statutory requirement, should be studied with the express purpose of either eliminating or amending the law to permit the State to let such contracts as this one to one bidder, instead of five, six, or more bidders, with none having authority over the others but all having the same privilege of screaming for help from the State Engineer on the job, whose own efficiency is diluted because too often he has to "mother" the disputing contractors, rather than perform his primary duty of progressing the job. Experience would indicate that under the prevailing system the State squanders huge sums of money in trying to keep the jigsaw puzzle together, whereas, under the one bid system, the responsibility of efficiency and coordination would not only be upon the one contractor but it would be to said contractor's financial advantage to move with coordination, efficiency and due speed to complete the contract, for the basic reason that the contractor could not place upon the shoulders of others, but only upon himself, any blame for a slowdown or uncoordinated work. $^{41}$

While this court recommended returning to the single-bid system, permitting the state to delegate the coordination duty to a CM could likewise resolve the inefficiencies. The CM would have the authority to direct the work of contractors.

dollars, shall prepare separate specifications for the following three subdivisions of the work to be performed:

a. Plumbing and gas fitting;

b. Steam heating, hot water heating, ventilating and air conditioning apparatus; and

c. Electric wiring and standard illuminating fixtures.

2. Such specifications shall be drawn so as to permit separate and independent bidding upon each of the above three subdivisions of work. All contracts awarded by any political subdivision or by any officer, board or agency thereof, or of any district therein, for the erection, construction, reconstruction or alteration of buildings, or any part thereof, shall award the three subdivisions of the above specified work separately in the manner provided by section one hundred three of this chapter. Nothing in this section shall be construed to prevent any political subdivision from performing any such branches of work by or through their regular employees, or in the case of public institutions, by the inmates thereof.

N.Y. STATE FIN. LAW $\S 135$ (McKinney 1974) governs all state contracts and is similarly worded.

39. General Bldg. Contractors v. County of Oneida, 54 Misc. 2d 260, 282 N.Y.S.2d 385 (Sup. Ct. 1967); accord General Bldg. Contractors v. City of Syracuse, 40 A.D.2d 584, 334 N.Y.S.2d 730 (1972), modified, 32 N.Y.2d 780, 298 N.E.2d 122, 344 N.Y.S.2d 961 (1973).

40. General Bldg. Contractors v. County of Oneida, 54 Misc. 2d at 260, 282 N.Y.S.2d 385, 388. The court relied in part on the fact that the legislature had expressly authorized shifting the duty to coordinate in the public authorities statute, which reads:

Construction contracts . . . let by the corporation shall be in conformity with the applicable provisions of section one hundred thirty-five of the state finance law, but the corporation in its discretion may assign such contracts for supervision and coordination to the successful bidder for any subdivision of work for which the corporation receives bids.

N.Y. Pub. Auth. LaW $\S 1287$ (1) (McKinney 1982). That provision has been construed to allow broad delegation of coordination responsibility for a complete project. See KEC Corp. v. New York State Envtl. Facilities Corp., 76 Misc. 2d 170, 350 N.Y.S.2d 331 (Sup. Ct. 1973).

Comparison of the state and municipality statutes with the public authorities statute indicates that New York courts have good reason not to imply a right to delegate the duty to coordinate. Reform must therefore come from the legislature, not from the courts.

41. Forest Elec. Corp. v. State, 52 Misc. 2d 215, 217-18, 275 N.Y.S.2d 91 7, 919-20 (Ct. Cl. 1966), affd, 30 A.D.2d 905, 292 N.Y.S.2d 589 (1968). 
Since the CM would bear the legal liability resulting from delays in the project, it would also be to his financial advantage to move with "due speed."

Public bidding statutes may work a second inefficiency by requiring that the $\mathrm{CM}$ contract be awarded to the lowest responsible bidder. Such nebulous qualifiers as "responsible" give little room for considering quality. The award of the CM contract is, however, perhaps the most essential award; the CM himself significantly affects both the quality of the work and the time needed for completion. Without a more rigorous procedure to examine the expertise of bidders seeking the CM position, the CM may well become the lowest common denominator in the construction process. ${ }^{42}$ The overall quality of work can be no better than the quality of the CM's performance. When this possibility exists, the owner's ability to achieve the objectives of quality and timely completion may outweigh his desire to shift some of the risks.

\section{III}

\section{A New Approach: Contractual Allocation of Risk to CM}

\section{A. Edwin J. Dobson, Jr., Inc. v. Rutgers: Recognition of the Owner's Successful Delegation of the Duty to Coordinate}

In the midst of the courts' reluctance to release the owner from liability for scheduling and coordinating work, Edwin J. Dobson, Jr., Inc. v. Rutgers ${ }^{43}$ is the sole example of an owner's successful delegation of the duty of coordination to a CM.44 As seen above, courts rarely look beyond contractual terms to analyze the true relationships among the parties in a construction contract and the expectations those parties bring into the transaction. However, the Dobson court's interpretation of a typical construction management arrangement allowed the owner to

42. South Carolina has designed a procedure which overcomes the restraints of the lowest bidder requirement. The CM, as well as the architect/engineer and land surveyor, are chosen by the building agency's selection committee comprised of persons who are "qualified to make an informed decision as to the most competent and qualified firm for the proposed project." S.C. CODE ANN. \$ 11-35-3220(1) (Law. Co-op. Supp. 1982). The committee issues invitations to firms to submit information. The invitation includes a description of professional services needed as well as a description of the work. Id. $\S 11-35$ $3220(2)$. Once the committee receives the information, it selects at least five firms for interviews. Id. $\S 11$. 35-3220(4). After interviews, the firms are ranked in order of qualification on the basis of "(a) past performance; (b) the ability of professional personnel; (c) willingness to meet time and budget requirements; (d) location; (e) recent, current and projected work loads of the firms; and ( $f$ ) related experience on similar projects." Id. § 11-35-3220(5). Contract negotiations are commenced beginning with the highest-ranked firm. If a satisfactory agreement cannot be reached, the state has the prerogative to terminate negotiations and contact the next-highest-ranked interviewee. Id. § 11-35-3220(7).

This system helps to ensure that the CM has the expertise needed while still providing the safeguards essential for any state contract.

43. 157 N.J. Super. 357, 384 A.2d 1121 (Law Div. 1978), affd sub nom. Broadway Maintenance Corp. v. Rutgers, 180 N.J. Super. 350, 434 A.2d 1125 (App. Div. 1981).

44. In John E. Green Plumbing \& Heating Co. v. Turner Constr. Co., 500 F. Supp. 910 (E.D. Mich. 1980), the court found an action against a CM for negligent performance of scheduling and coordination to be barred by the "no damage for delay clause" in the contract between the owner and contractor. However, since the court never addressed whether the CM or the owner had the power to enforce a schedule, it never really reached the question of who, between the owner and CM, had ultimate responsibility. The court did allow a cause of action against the CM for intentional interference with contractual relations. 
delegate all coordination duties. This interpretation may be some indication of how such cases will be analyzed in the future.

The facts of this case are fairly complex. In building a new medical school, Rutgers entered into six prime contracts, including one with Frank Briscoe Co., Inc., (Briscoe) for general construction, one with Edwin J. Dobson, Jr., Inc., (Dobson) for plumbing and fire prevention, and one with Broadway Maintenance Corp. (Broadway) for electrical work. Briscoe's role in the project was essentially that of a CM, although it was not specifically referred to as such. Briscoe was to be the "supervisor, manager, overseer, coordinator and expediter of all of the Contractors and of the total construction process and all of its parts."45 Rutgers in turn "relie[d] upon the organization, management, skill, cooperation, and efficiency of [Briscoe] to supervise, direct, control and manage the General Construction work and the efforts of the other Contractors, so as to deliver the intended building conforming to the Contract and within the scheduled time."46 The other contractors also agreed to rely on the control and management of Briscoe for completion of the project on time. ${ }^{47}$

Rutgers employed a critical path method (CPM) consultant to devise a diagram and schedule for the most efficient plan for completing the project. Briscoe was to "incorporate and enforce the combined schedule as his own."48 Each of the other contractors agreed "to cooperate and coordinate his own operations in order to meet effectively all scheduled task deadlines." 49 The CPM-estimated time for completion of 700 days was included in all the contracts. Dobson's work was completed twenty-five months after the estimated completion date, and Broadway's performance took twenty-nine months more than estimated.

Briscoe, Dobson, and Broadway filed suit against Rutgers for failure to coordinate and supervise the construction work. The State of New Jersey, which had assumed all contracts, defended primarily on the ground that the duty for coordination lay with Briscoe under the terms of the contract. Before the consolidated cases came to trial, Briscoe settled its major claims with the state. ${ }^{50}$ The trial court held that the owner had in fact delegated the duty to coordinate to Briscoe and that Briscoe had the necessary means to enforce its responsibility by bringing suit against a delaying contractor on either a direct contract theory or a third party beneficiary theory. ${ }^{51}$ The appeals court likewise held that the contract language gave the duty to coordinate to Briscoe, but found that Briscoe could bring an enforcement suit only on a third party beneficiary theory. ${ }^{52}$

1. Direct Contract Cause of Action. The plaintiffs' claim that Rutgers had an

45. Dobson, 157 N.J. Super. at 367,384 A.2d at 1125 .

46. Id. at 367,384 A. $2 \mathrm{~d}$ at 1126 .

47. Id.

48. Id. at 368 n.4, 384 A.2d at 1126 n.4.

49. Id.

50. The state retained some counterclaims against Briscoe for indemnification for the claims of Dobson and Broadway, as provided in the contract. See contract provision G4-D.2 printed at id. at 374, 384 A.2d at 1129 .

51. Id. at 411,384 A.2d at 1149 .

52. Broadway Maintenance Corp. v. Rutgers, 180 N.J. Super. 350, 434 A.2d 1125 (App. Div. 1981). 
implied duty to coordinate the project was based on two premises: (1) that the plaintiffs had privity only with Rutgers and (2) that Rutgers had practical control over the project since it was the only party who could withhold funds or terminate a contractor. ${ }^{53}$ The court, however, focused on the contract language which specified that Briscoe would coordinate all construction and that all other contractors would rely on his management of the work. ${ }^{54}$ Since the same language was a part of the general conditions of each contract, these provisions were binding on Dobson and Broadway despite their lack of privity with Briscoe, ${ }^{55}$ thus giving rise to a breachable duty on which any contracting party could sue.

A second basis for a direct contract action was the agreement of all parties to coordinate the scheduling of their work. ${ }^{56}$ By the terms of the general conditions, all the contractors agreed to follow the CPM schedule and cooperate with Briscoe's enforcement of the schedule. ${ }^{57}$ To enable the CPM to develop a workable schedule, all the contractors had to furnish certain information to the consultant. The court found that in furnishing such information the contractors "essentially agreed with one another that the work would be performed in that manner, sequence, and time." 58 Moreover, Rutgers could not be liable for delays resulting from the scheduling arrangements because it was not a party to the development of the schedule; it had specified neither the manner nor sequence of performance and had had no input into the process. ${ }^{59}$ The scheduling process thus gave rise to a contract right only among those involved in its development, i.e., the prime contractors. ${ }^{60}$

2. Third Party Beneficiary Cause of Action. The trial court also found that since Briscoe was a third party beneficiary to the plaintiffs' contracts with Rutgers, its ability to sue on that theory was an alternative effective means of enforcing its duty to coordinate. ${ }^{61}$ This cause of action was viewed as devolving from a provision in the general conditions requiring any contractor who caused an unnecessary delay to pay all costs and expenses incurred by other parties as a result of that

53. For cases implying an owner's duty to coordinate, see Paccon, Inc. v. United States, 399 F.2d 162 (Ct. Cl. 1968); L.L. Hall Constr. Co. v. United States, 379 F.2d 559 (Ct. Cl. 1966); Peter C. Camilli \& Sons v. State, 41 Misc. 2d 218, 245 N.Y.S.2d 521 (Ct. Cl. 1963).

54. See supra text accompanying notes $45-46$.

55. Dobson, 157 N.J. Super. at 410,384 A.2d at 1148 . Broadway had argued this point, perhaps too convincingly, in contending that another provision of the general conditions was binding on all parties. See id. at 399,384 A.2d at $1142-43$.

56. The court never articulated whether these were independent bases giving rise to separate causes of action, or whether the combined force of both was the grounds for recovery. See Sneed, supra note 8 , at 370 .

57. See supra text accompanying notes $48-49$.

58. Dobson, 157 N.J. Super. at 404,384 A.2d at 1145.

59. Should the owner interfere with or abandon the CPM schedule, however, he becomes liable for resulting delays. See Natkin \& Co. v. George A. Fuller Co., 347 F. Supp. 17 (W.D. Mo. 1972).

60. On appeal, the court recognized a cause of action arising from only a third party beneficiary theory, not from a contractual basis. See supra note 52 and accompanying text. Such reasoning is consistent with the proposition that the duty to coordinate is as strong as the power to enforce the orders. See Paccon, Inc. v. United States, 399 F.2d 162, 169-70 (Ct. Cl. 1968). Otherwise, the power to enforce the duty would be equivalent to the power to write certain provisions into the contract.

61. Dobson, 157 N.J. Super. at 407,384 A.2d at 1146. 
delay. ${ }^{62}$ Applying traditional third party beneficiary theory, the court focused upon the persons to whom performance was to be rendered in determining whether the intent to benefit was present; if performance was to be directly rendered to the third party, that party was intended to benefit and could enforce the contract. Otherwise, the party was an incidental beneficiary who could not enforce the contract. ${ }^{63}$

Since the contractors had agreed not to make claims against the owner for damages, the court reasoned that the contractors intended to relieve the owner of liability and to look instead to the delaying contractor for damages. ${ }^{64}$ Because the performance of each contractor's promise to pay for delay was to be rendered directly to the other contractors, each contractor was found to have intended to benefit the other primes, giving rise to a cause of action to every other prime. Thus, Briscoe was a third party beneficiary of Broadway's and Dobson's promises to pay damages for unnecessary delays.

Although the appeals court also focused on the intent of the contracting parties, it relied on the contract language requiring coordination of work with other contractors to find such an intent to benefit each other. Given the direct benefit each contractor would receive from the performance of other primes, the court concluded that the parties intended Broadway and Dobson to be beneficiaries of the Briscoe-Rutgers contract. They could therefore sue Briscoe for failure to coordinate the work. 65

62. Id. at $408,384 \mathrm{~A} .2 \mathrm{~d}$ at 1147 .

63. Id. at 410, 384 A.2d at 1148; see L. Simpson, ConTracts $\$ 117$ (2d ed. 1965). An exception to this generalization is noted at RESTATEMENT OF CONTRACTS $\$ 133$ comment $d$ (1932).

64. Dobson, 157 N.J. Super, at 408-09, 384 A.2d at 1147.

65. Broadway Maintenance Corp. v. Rutgers, 180 N.J. Super. 350, 357-58, 434 A.2d 1125, 1129 (App. Div. 1981). The appeals court never stated whether it was necessary for Briscoe to have some means of enforcement to assume the duty of coordination. Since the court analyzed the right to sue from the view. point of Broadway and Dobson suing Briscoe, the opinion could be read as requiring a third party beneficiary theory only as a means of recovering damages for delay from the CM, not as being an essential element of the duty to coordinate.

The courts' recognition of a third party beneficiary cause of action represents a growing awareness that "the interrelationships, interdependency and reliance upon the promises and performances of others which pervade the construction field necessitate rules which are more responsive to the needs of the industry." Comment, Contracts for the Benefit of Third Parties in the Construction Industry, 40 FORDHAM L. REV. 315, 322-23 (1971). Given the close relationships existing in the construction field, allowing third party beneficiary actions is inherently sensible. When a contract creates a benefit which is to be conferred on a third party, that party has a reasonable expectation of receiving that benefit and frequently justifiably changes his position in reliance on that expectation. Id. at 322; see also A. CorbIN, CORBIN ON CONTRACTs $\S 775$ (onevol. ed. 1952). When that third party is injured, allowing him to directly litigate his claim without multiple and circuitous suits certainly seems preferable. Since the gravamen of the cause of action arises from the interdependent relationship of participants in the industry, no contractor is exposed to suits from parties uncontemplated in the original contract. Comment, supra, at 323-26.

The greatest bar to finding a third party beneficiary relationship has been the difficulty in applying the "intent-to-benefit" test. In the absence of an express statement of intent to benefit another contractor, the courts usually find the third party to be only an incidental beneficiary. A. CoRBIN, supra, § 779D; see Comment, supra, at 320-21. Some notable exceptions to this general rule are Flinkote Co. v. Brewer Co., 221 So. 2d 784 (Fla. Dist. Ct. App. 1969); Thomas G. Snavely Co. v. Brown Constr. Co., 45 Ohio 2d 41 , 239 N.E.2d 759 (C.P. 1968); County of Giles v. First U.S. Corp., 223 Tenn. 245, 445 S.W.2d 157 (1969). In litigation involving suits between coprime contractors, however, there is a growing acceptance of coprimes as intended beneficiaries of the contracts between the other primes and the owner. In the leading case of M.T. Reed Constr. Co. v. Virginia Metal Prods., 213 F.2d 337 (5th Cir. 1954), the three primes' contracts all included agreements to coordinate their work and cooperate to ensure timely completion. Each con- 
3. Means of Enforcement. In approving causes of action against other primes as a means for Briscoe to enforce its duty to coordinate, the trial court in Dobson apparently accepted the premise that the duty to coordinate is only as effective as the means to compel compliance. ${ }^{66}$ The court declined, however, to accept the correlative premise that the ability to impose sanctions on a contractor is equivalent to the duty to coordinate. ${ }^{67}$ For example, the trial court refused to imply a duty to coordinate from Rutgers' power to withhold money or to terminate a defaulting contractor. To imply such a duty in Rutgers would have defeated the basic purpose of entering into the contract with Briscoe: to delegate the responsibility for the everyday coordination of the work's progress and thereby to avoid any resulting liability for failure to achieve the desired goal. ${ }^{68}$

The court stated that the "effective means of enforcing the contract is not the ability to withhold funds or to terminate, but to sue and to enforce according to the remedies provided by law."69 In the very next sentence, however, the court recognized the shortcoming of this remedy: "Fortunately, most contractors honor their commitments or the courts would be overwhelmed."70 The contractor who is injured by the delay of another contractor will be benefited little if the construc-

tractor also agreed to pay the cost of any defective work, and in a mutual responsibility clause, each contractor agreed to pay for any damage which he caused another contractor. The court found that the "mutual obligation" to coordinate their work was essential to completion of the job and was in fact a part of the consideration which "induced each of the contractors to undertake its particular job at the agreed price." Id. at 338.

While the Broadway court stressed the above portion of the Reed opinion, the Reed court actually suggested that it was the duty to pay for damages which created the cause of action.

[T] he contract in suit made the several contractors direct beneficiaries of the contractual provision that any contractor would be liable for any actual damages inflicted upon another contractor on this job because of the breach of any duty assumed under the contract by the contractor. When to this there was added the contractual obligation, upon due notice, to settle with such contractor by agreement or arbitration for the damage caused, the local law created the right of action or caused it to arise out of the facts.

Id. at 339 .

Thus, wherever a coprime contractor has agreed to coordinate his work with that of other primes and/or to pay damages to the other primes caused by his delay, the courts will apparently be willing to recognize the third party prime's right to sue under the contract. See also J. Louis Crum Corp. v. Alfred Lindgren, Inc., 564 S.W.2d 544 (Mo. Ct. App. 1978) (court found "reciprocal relationship" giving rise to cause of action); KEC Corp. v. New York State Envtl. Facilities Corp., 76 Misc. 2d 170, 350 N.Y.S.2d 331 (Sup. Ct. 1973) (promises to indemnify owner and reimburse other parties for damages created cause of action); Visintine \& Co. v. New York, C. \& St. L. R.R., 169 Ohio St. 505, 160 N.E.2d 311 (1959); T\&R Duncanson v. The Scottish County Investment Co., 1915 Sess. Cas. 1106 (Scot. Sheriff Ct.) (dicta). Contra Peter Kiewit Sons' Co. v. Iowa S. Utils. Co., 355 F. Supp. 376 (S.D. Iowa 1973) (despite coordination and mutual responsibility clauses, coprimes not entitled to cause of action because the intent to benefit was not clearly expressed in the contract language and the coprimes did not have the exclusive interest in the CM's performance).

66. See, e.g., Paccon, Inc. v. United States, 399 F. Supp. 162, 169-70 (Ct. Cl. 1968).

67. See Tippetts-Abbett-McCarthy-Stratton v. New York State Thruway Auth., 27 Misc. 2d 522, 212 N.Y.S.2d 263 (Ct. Cl. 1961) (engineer had contractual duty to coordinate and supervise, but owner held liable to engineer for delays caused by prime contractor because the owner possessed the sanctions), modified, 18 A.D.2d 402, 239 N.Y.S.2d 732 (owner held not liable for delay damages because engineer failed to meet high burden of proof that "no possible exercise of reasonable judgment or fair dealing . . would have excused" the owner from exercising its sanctions), affd, 13 N.Y.2d 1091, 196 N.E.2d 64, 246 N.Y.S.2d 409 (1963).

68. Dobson, 157 N.J.. Super. at 405,384 A.2d at $1145-46$

69. Id. at $407,384 \mathrm{~A} .2 \mathrm{~d}$ at 1146 .

70. Id. 
tion manager's only method of enforcement is to sue and get a judgment after the job is completed. ${ }^{71}$

In the Dobson case, final disposition came ten years after construction was completed. In addition to the obvious risk of bankruptcy of the delaying contractor in such a lengthy period, the injured contractor will certainly not be compensated for its loss when the need for damages is likely to be greatest, that is, immediately after the injury. Realistically, the CM's sanctions are redueed to recovering damages; there will be no real immediate action which can be taken (other than mere threat of suit) to compel timely performance of the job.

In contrast, the owner's retained powers to withhold money or terminate a defaulting contractor provide a much more effective remedy against the recalcitrant contractor. The owner, however, is faced with a dilemma in determining how many of his sanctions to transfer to the CM. Delegating the power to withhold money or terminate a contractor would make clear where the duty to coordinate lies as well as providing an effective enforcement tool to the CM. In such a delegation, however, the owner risks losing all ability short of suit to effectively protect his own interests. ${ }^{72}$

\section{B. An Alternative Approach}

The Dobson court's recognition that the owner may delegate his responsibility despite retaining power is consonant with the view that the duty to coordinate is broader than the sanctions available to a party.

The emphasis on sanctions. . . masks the fact that some coordination duties may exist independently of the sanction powers. For example, if the owner is supposed to resolve conflicts between contractors, he may be called upon to do so even when the contractors are performing properly and thus sanctions are not warranted. Coordination, then, is essentially a job management function. It depends not so much on the ability to impose sanctions as on the ability to apply contractual pressure. . . . [T]he power to impose sanctions as such is not required as an element of the duty to coordinate. That duty exists even where there is no such power. What is required is the contractual ability to influence the contractors. ${ }^{73}$

71. Goldberg, supra note 5, at 390. Moreover, any successful suit by the CM against the delaying contractor that would make the CM another obligee of the contractor's performance bond would certainly dilute the amount of the bond. It would decrease the value of the bond to the owner because, upon default, the contractor would only be able to pay the owner what he has not already paid to the CM. Such a threat to the owner's security might cause an immediate halt to construction and thus would not be the most efficient means by which a CM could enforce his coordination responsibilities.

72. Id. at 400 .

73. Id at 39 1-92 (citations omitted). In two cases, courts have found certain contract language strong enough to require the owner to coordinate the progress of the work, without any reference to the sanctions available to the owner. In Hoffman v. United States, 340 F.2d 645 (Ct. Cl. 1964), and Shea-S\&M Ball v. Massman-Kiewit-Early, 606 F.2d 1245 (D.C. Cir. 1979), the owners were found to have duties to invoke their contractual authority to compel cooperation among the contractors. The contract in Hoffman provided that "[ $\mathrm{t}$ ]he State shall conduct operations so as to cooperate fully with any such work being performed by the Government and/or Government contractors and shall carefully fit its own work to that provided under other contracts as directed by the Contracting Officer." 340 F.2d at 649 (emphasis deleted). The Shea-SGM Ball contract provided that the owner could "undertake or award other contracts for additional work, and the Contractor shall fully cooperate with such other Contractors and [the owner's] employees and carefully fit his own work to such additional work as may be directed by the Contracting Officer." 606 F.2d at 1250. In each case, the owner's failure to invoke its contractual rights to require cooperation was found to be the basis for liability. While the courts never reached a determination of what 
Thus, the duty to coordinate arises not from the owner's status as owner nor from his power as keeper of the purse but from his position as the overall manager of the construction and as the party with the greatest contractual influence.

The nonprofessional owner, however, does not possess the expertise needed to adequately supervise the construction and exercise his sanctions in the most effective manner. When the duty is viewed as arising from the bases of managerial function and contractual influence, the owner should be free to delegate his power to the party with the expertise to wield the power effectively-the CM. In transferring the managerial functions to the CM, the owner may establish stronger contractual influence between the CM and other prime contractors. At the same time, the owner may retain some separate sanctions to protect his own interests.

Under its Dobson contract, Briscoe certainly had the contractual authority to compel cooperation among the contractors. The contract made clear that all parties were relying on Briscoe for coordination of the work. ${ }^{74}$ Furthermore, Briscoe was to enforce the schedule, and the other contractors promised to cooperate with him. ${ }^{75}$ Such leverage given to the CM in the contract should be deemed sufficient to delegate to the CM the duty to coordinate, independent of enforcement sanctions available to the CM or to the owner.

An owner might specifically include in each party's contract a description of its responsibilities and for whose benefit they are intended. The owner may protect his interests by reserving the right to hold back retainage sufficient to protect him from defective work. Since no owner would relinquish such a right, retaining that sanction is unlikely to be interpreted as retaining the duty to coordinate. However, various other factors may intervene to support a holding that the owner reserves the duty to coordinate. If the CM's directives are ignored by other contractors so that the owner intervenes to support the CM, the owner's claim of total delegation of duty may not be accepted. It is possible that the owner could be liable for negligence in selecting the CM, despite a contractual disclaimer of liability. Finally, the owner will be liable if he in fact assumes the actual coordination responsibilities, despite contractual language to the contrary. ${ }^{76}$

One untested alternative would be for the contract to provide first that the owner will exercise his supervisory powers for his benefit alone and not for the contractors' benefit. A second clause would absolve him from liability if he exercises these powers. With these two clauses, the owner would have the power to coordinate the job to the extent necessary and yet incur no liability whether or not he exercises his power. The contract terms themselves would exclude the possibility that any contractor could reasonably rely on the owner to coordinate.

must be done to meet this duty, in both cases the arrangement of an unsuccessful conference between contractors was deemed insufficient.

No reference was made to any sanctions which could be imposed to encourage contractors to cooperate. However, since the contracts required that the owners coordinate the work, they had duties to exercise that contractual authority.

74. See supra text accompanying notes 45-46.

75. See supra text accompanying note 47.

76. See Natkin \& Co. v. George A. Fuller Co., 347 F. Supp. 17, 36 (W.D. Mo. 1972). 


\section{IV}

\section{Means of Sharing Risk in a Construction Job}

Many mechanisms have been developed for shifting risk of loss among participants in complex enterprises. A rule of policy has emerged over the years which sanctions deliberate allocation of risk. For example, an employer is vicariously liable for the torts of his employee. Such negligence is, as a practical matter, certain to occur in the conduct of the employer's enterprise. The risk of such liability is in reality placed upon the entire enterprise as a required cost of doing business. The employer is able to distribute the losses throughout society, by means of liability insurance premiums and price increases.

Construction is a field in which the attendant risks are as serious and numerous as those facing a large employer. At first glance, the nonprofessional owner seems to be well shielded through payment and performance bonds required of contractors and subcontractors and through errors and omissions insurance carried by design professionals. Nevertheless, many gaps exist whereby the owner is not covered by any of these devices. Moreover, with the introduction of the CM as another actor, the risk of liability increases for both the CM and the owner. Inevitably, those claims which are brought against the CM will be brought against his "employer," the owner.

This section first discusses the various gaps in the protections available to the owner. Second, it discusses the resultant allocation or reallocation of the risk of negligent and nonnegligent error in the progress and construction of the project.

\section{A. Owner's Exposure to Liability and Devices Which Purport to Limit It}

1. Payment and Performance Bonds. Owners are generally protected from a contractor's bankruptcy and subsequent inability to finish a job by a contractual provision requiring a performance bond. ${ }^{77}$ Under such a bond, a surety promises either to step in and complete the contractor's job or to pay the owner's contract price and allow him to retain the defaulting contractor or hire a new one. Payment bonds on the other hand protect the owner from the liens of materialmen and laborers while protecting the rights of these suppliers and employees to be compensated. When the federal government is the owner, the Miller Act ${ }^{78}$ provides for payment to materialmen and laborers. ${ }^{79}$ State governments have their own counterparts of the Miller Act, and the obligations assumed by bond or imposed by statute vary greatly. ${ }^{80}$

77. When the contract contemplates the owner's making direct payments to trade contractors, however, the necessity for a payment bond from the general contractor is obviated.

78. Ch. 642, 49 Stat. 793 (1935) (codified as amended at 40 U.S.C. $§ 270$ (1976 \& Supp. 1981)).

79. Statutory provisions extending this [Miller Act] bond protection to private work have been held to be constitutional. Such bonds are now required by statute in California, Florida, Louisiana, Mississippi, Utah, Texas, West Virginia and Wisconsin. There is no pattern of uniformity with respect thereto. Such legislation may either supplement the supplier's right to a mechanic's lien or provide that the right under the bond shall be in substitution for the right under the mechanic's lien statute.

E. Cushman, R. Cushman \& K. Cushman, Bonds on Public Works, in Credit Manual of Commercial Laws 769, 773 (Nat'l Assoc. Credit Man. ed. 1981).

80. See E. Cushman, R. Cushman \& K. Cushman, State Bond Laws, in CredtT Manual or CommerCial LAW's 792 (Nat'l Assoc. Credit. Man. ed. 1981), for a discussion of a Miller Act state counterpart in 
The owner may not be as well protected as he believes, however. In many instances, the liability of the surety to the owner under a performance bond may not be coextensive with the liability of the contractor. Either the surety or the contractor may have valid defenses against the owner's claim. For example, the owner must not release any retainage or pay the contractor a greater percentage of the contract price than was actually earned. ${ }^{81}$ This arrangement is designed to guarantee that the surety has a sufficient balance to complete the job or satisfy unpaid bills of the contractor. When the owner pays more than the contractor is entitled to, the surety is discharged. Discharge of the surety also occurs if the owner accepts work which does not substantially conform to the contract terms. ${ }^{8: 2}$ The surety may be discharged if the owner requests a substantial and material alteration in the underlying contract which materially changes the surety's risk, without obtaining the surety's consent to the change. ${ }^{83}$ Some states do not even require that the surety be prejudiced by the material alteration, ${ }^{84}$ making the owner's risk of liability particularly high if he changes the contract substantially. The owner may thus inadvertently lose the protection of the surety's full performance or payment. ${ }^{85}$

Similarly, the obligation of the surety and contractor may not be coextensive where the contractor specifically agrees to indemnify the owner for the contractor's negligent acts. In this situation, the contract generally requires that the contractor obtain liability insurance. If the contractor does not obtain this insurance, the owner's acquiescence in the commencement of work may operate as an estoppel when the owner seeks an enforcement upon the surety of the indemnification provision of the contract. ${ }^{86}$

Furthermore, unless the surety promptly chooses between his options upon default of the contractor, the value of the bond to the owner may be considerably diminished. ${ }^{87}$ For example, the owner may lose the bond's protection if, upon the

each of the fifty states. The amount to be bonded varies widely from state to state, with some requiring that it be $100 \%$ of the contract price (Delaware), some requiring that it not be less than one-half the contract price (Colorado), and some making no special requirements (Florida-except for highway contracts).

81. Sureties have been successful in asserting the defense of overpayment due to the relative ease with which proof of prejudice can be established. Carnaghan, Deviations in Re-let Contracts, Pro Tanto Discharge of Surety to Extent Prejudicial, 10 FORUM 63, 72 (1974).

82. See Murphy v. State ex rel. Jackson School Township, 90 Ind. App. 432, 168 N.E. 875 (1929). For exceptions which may preclude the contractor and his surety from asserting the owner's acceptance of the work and subsequent release of monies as a defense, see Annot., 109 ALR 625, 628-30 (1937).

83. RESTATEMENT OF SECURITY $\$ 128$ (1941). If the bond is a payment bond rather than a performance bond, the surety will not likely be able to plead change in the principal contract as a defense to labor and material claims. For a full explanation, see United States Fidelity \& Guar. Co. v. Borden Metal Prods. Co., 539 S.W.2d 170 (Tex. Civ. App. 1976).

84. See, e.g., Verduga Highlands, Inc. v. Security Ins. Co., 240 Cal. App. 2d 527, 49 Cal. Rptr. 736 (1966); Cal. Civ. CoDE $\$ 2819$ (West 1974).

85. Verduga Highlands, Inc. v. Security Ins. Co., 240 Cal. App. 2d 527, 533, 535, 49 Cal. Rptr. 736, 740,742 (1966).

86. But see Safeway Stores v. Massachusetts Bonding \& Ins. Co., 202 Cal. App. 2d 99, 20 Cal. Rptr. 820 (1962).

87. Moreover, some owners initially require that a contractor obtain a bond but, if he is successful, waive it in order to save the cost of the premium, on the theory that if a responsible surety conpany will bond the contractor he really does not need one. The problem is that sureties, too, make mistakes. From 
default of the contractor, the surety chooses to complete at its expense rather than paying the owner the contract price. There may be so much delay from the surety's "shopping" for a new contractor that the presumed advantage of having a bond evaporates.

Nonprofessional owners also suffer when courts erode the distinctions between performance and payment bonds. There are often attempts by laborers and materialmen, absent a true third party beneficiary payment bond, to convert by court decision a true performance and indemnity bond into an express or implied third party beneficiary obligation. A certain judicial "paternalism" is exercised by courts in favor of laborers, subcontractors, and materialmen in these instances. Courts overlook the fact that the owner is principally interested in completing the project for the contract price and keeping it free from liens. Courts should not so easily presume that the owner intended laborers and materialmen to have third party beneficiary rights under the performance bond. ${ }^{88}$ Nevertheless, many state courts find that third party beneficiary rights may be conferred by "implied" intent where they are not expressly excluded by the contract or bond and where it appears that the materialmen will not otherwise be paid. ${ }^{89}$

What are the implications for the owner and the surety when courts find, as in the Dobson case, that one prime is liable to another prime for delay based on a third party beneficiary doctrine, particularly when the defaulting prime has assumed some obligation for coordination or scheduling? ${ }^{90}$ Can the contractor who is damaged take advantage of the defaulting contractor's performance bond? Fortunately for the surety (and the owner) it is merely a guarantor rather than a performer. The surety's guarantee usually runs solely to the named obligees, unless the bond's language shows a contrary intent. ${ }^{91}$ Thus the delayed con-

the point of view of the owner, it is ironic that contractors from whom the owner least needs to require bonds (due to their character, capacity and capital) are the only ones most sureties will consider bonding. Further, some sureties condition their obligations to "performance of the work" and do not incorporate the terms of the construction contracts. Under this kind of bond, the surety may limit its obligation to the narrow guarantee that the work will be performed, leaving the owner responsible for unpaid bills incurred by the contractor before his default and for the damages suffered by the owner as a result of late completion.

88. When the owner on a public construction job requires the general contractor to carry a payment bond, it is strong evidence of an intent to benefit subcontractors and materialmen because a mechanic's lien may not be filed against public property. But if the owner is a private one, it is less clear that the intent of the parties in requiring the bond is equally for the benefit of the third party laborers and materialmen. After all, it is the owner who is protected from having to pay the claims that the general contractors should have paid. See Fidelity \& Deposit Co. v. Rainer, 220 Ala. 262, 264, 125 So. 55, 56-57 (1929).

89. See, e.g., Royal Indem. Co. v. Alexander Indus., 58 Del. 548, 211 A.2d 919 (1965); Amelco Window Corp. v. Federal Ins. Co., 127 N.J. Super. 342, 317 A.2d 398 (App. Div. 1974). Such attempts against the federal government as owner, under a Miller Act performance bond, have been unsuccessful, however. See, e.g., James E. Simon Co. v. United States ex rel. Ardelt-Horn Constr. Co., 316 F. Supp. 254 (D. Neb. 1970), affd, 446 F.2d 820 (8th Cir. 1971), cert. denied, 404 U.S. 1060 (1972); Sun Ins. Co. v. Diversified Eng'rs, 240 F. Supp. 606 (D. Mont. 1965).

90. If the obligee-owner were subject to a judgment by a prime contractor for delay damages, could the owner assert the judgment obtained, against the defaulting prime, for failure to perform its contract? And does this create a right to indemnity against the prime's (principal's) surety under the performance bond? There is little if any case law on this line of reasoning.

91. There are no rights to sue on a private works performance bond other than those held by the obligees named in the bond. See, e.g., National Am. Bank v. Southcoast Contractors, 276 So. $2 d 777$ (La. Ct. App. 1973). 
tractor, even though a third party beneficiary of the defaulting contractor's contract, has no rights on the defaulter's performance bond.

In Healy Plumbing $\mathcal{E}^{2}$ Heating Co. v. Minneapolis-St. Paul Sanitary District, ${ }^{92}$ the court recognized the impropriety of such a third party beneficiary claim against the performance bond of another contractor:

If a party not included within the class for whose protection the bond is given is permitted to sue on a tort claim or on a claim not connected with the performance of the contract, it is conceivable that the amount of the bond might be so dissipated that those for whose protection it is given would be left without any protection at all. ${ }^{93}$

2. Indemnification Clauses. Another method of risk shifting is the use of indemnity or "hold-harmless" clauses which eliminate the owner's cost of potential litigation against the defaulting contractor. In their most limited form, such clauses require contractors to defend any suit or pay any judgment arising out of their negligent acts or omissions. At the other end of the spectrum, some agreements require the contractor to indemnify the owner even when the contractor is not responsible for the loss. In between, there exist "intermediate" clauses which bind the contractor to pay if he is responsible for any part of the negligence leading to damage or injury. However, the utility of such clauses is severely diminished by state legislation; more than half of all states have legislation which prohibits or modifies liability under hold-harmless provisions when the injury or damage arises solely from the negligence of the party whose liability would be extinguished by the clause. ${ }^{94}$ Some of these same states will invalidate "intermediate" hold-harmless provisions where there is joint liability with the party indemnified.

3. Performance Guarantees. Another provision which may be written into the contract to protect the owner is a contractor's guarantee of his own performance. There exists, however, some strong judicial resistance to allowing owners, contractors, architects, and other members of the construction industry to freely allocate contractual responsibility among themselves. ${ }^{95}$

In a recent California decision, an owner sought to allocate any risk of error from a design change to the party initiating the change, the contractor. ${ }^{96}$ The

92. 284 Minn. 8, 169 N.W.2d 50 (1969).

93. Id. at 16, 169 N.W.2d at 55 (emphasis added); see also J. Louis Crum Corp. v. Alfred Lindgren, Inc., 564 S.W.2d 544, 549-50 (Mo. Ct. App. 1978)

94. Businessman's Guide, supra note 15 , at 304 , lists the following states: California, Delaware, Florida, Georgia, Hawaii, Idaho, Illinois, Indiana, Maryland, Michigan, Mississippi, New Hampshire, New Mexico, New York, North Carolina, North Dakota, Ohio, Oregon, Pennsylvania, Rhode Island, South Dakota, Tennessee, Texas, Utah, Virginia, Washington, and West Virginia.

95. Warranty law, when applied to construction contracts, is complex for the same reasons the construction process itself is complex: There are many parties, all with strongly divergent interests, yet all with interdependent responsibilities. Moreover, construction warranties partake of some of the characteristics of a sale of services, to which the UCC's warranty law is inapplicable, and some of the characteristics of UCC sales of goods; they are hybrids. For this reason, in some states only express warranties will be recognized on construction contracts; in other states both express and implied warranties will be recognized. Moreover, some states will use the UCC to imply a warranty, some will use it only by analogy, and some will reject it and rely on the common law to determine if a warranty exists. See Air Heaters v. Johnson Elec., 258 N.W.2d 649 (N.D. 1977), for an example of a more "modern" decision describing circumstances under which an implied warranty of finess for a particular purpose may be applicable to a construction contract.

96. Habenicht \& Howlett v. Jones-Allen-Dillingham, No. 1 Civ. 46449 (Cal. Ct. App. Dec. 29, 1981). 
court of appeals refused to give full legal effect to the contractor's performance guarantee on the basis that "[c]ontractors are not guarantors of the quality of designs furnished to them by an architect."97 The court relied on two decisions ${ }^{98}$ which held that when plans and specifications are furnished by an architect to a contractor and must be followed precisely, any "guarantee" by the contractor referring to performance merely constitutes a statement of purpose and extends only to workmanship. Moreover, because the architect's errors and omissions carrier insured only against negligent errors and because the error here was a nonnegligent one, the insurance would not cover the loss.

Because the court of appeals' and the lower courts' opinions negate the effect of the language of an express performance guarantee agreed upon by the parties, the sufficiency of performance guarantees in allocating risks is questionable. The ability of parties to delegate responsibility for coordination is similarly open to judicial manipulation.

4. Errors and Omissions Insurance for Design Professionals. 99 Architects and engineers are clearly agents of the owner in the construction process. For this reason, whatever claims can be brought against these professionals can be brought against the owner as well. The risk is shifted by insuring the professionals with errors and omissions insurance.

In recent years, however, the cost of architects' and engineers' professional liability insurance has increased dramatically while the coverage has been restricted severely by exclusions. ${ }^{100}$ Thus, if an owner is held liable to a third party as a result of advice from the architect to the owner, and if the architect subsequently becomes judgment-proof for any reason, the owner is without recourse should the acts of the architect fall into any of the numerous exceptions to coverage. A more

It seems especially appropriate for a contractor to bear responsibility for guaranteed performance where, as in the Habenicht case, the contractor's expertise concerning the design at issue is superior to that of the architect. See J. SWeet, Legal Aspects of ARchitecture, Engineering and the Construction PROCESS (1970).

97. Habenicht \& Howlett v. Jones-Allen-Dillingham, No. 1 Civ. 46449, slip op. at 11 (Cal. Ct. App. Dec. 29,1981 ).

98. Bush v. Jones, 144 F. 942 (3d Cir. 1906), and Kurland v. United Pac. Ins. Co., 251 Cal. App. 2d 112, 59 Cal. Rptr. 258 (1967).

99. This article will not consider "builder's risk insurance," which protects the structure against loss during construction, nor "general liability" insurance, which protects the public from bodily injury or property damage.

100. The typical policy excludes coverage for the following: performance of services not customary to the architect or engineer, the giving of insurance and bonding advice, the failure to complete work on time, projects in which the professional has any ownership interest, express warranties or guarantees, inaccuracy of estimates of probable cost, projects in which the professional performs any construction, and projects for which the professional's compensation is contingent in whole or in part on the sale of units based on the design. Hapke, Construction Industry Contracts, 23 ST. Louis U.L.J. 249, 255 (1979).

Most, if not all, errors and omissions insurance policies available to architects in the United States are written on a "claims made" basis. Therefore, there is the possibility that a claim made several years after completion of construction will not be covered if the architect has been cancelled or discontinues the insurance after performing the work of the agreement. An architect might be very reluctant to agree to carry errors and omissions insurance for an extended time beyond his performance under the agreement.

Berg \& O'Leary, Preparation of Owner-Archited Agreements From the Owner's Viewpoint, in BusINEsSMAN's GuIDE, supra note 15 , at 69,88 . 
serious trend has seen some architects and engineers decide that the cost of errors and omissions coverage exceeds its practical value and begin practicing their professions "naked," i.e., without insurance coverage. ${ }^{101}$ In the absence of legislation requiring architects and engineers to carry errors and omissions insurance, those individuals who make an economic decision not to carry insurance may force owners to pay claimants the difference over what the claimant can collect from the architect or engineer for a wrong committed by that professional.

\section{B. Allocation of Risk of Nonnegligent Error}

One major gap in the protection provided by suretyship and insurance occurs when a problem cannot be traced to the error of any one person. None of the mechanisms described above allocates the risk of nonnegligent error. The following examples illustrate this situation as it affects the architect, the owner, the $\mathrm{CM}$, and the contractor.

The general problem can be seen by postulating a situation in which advice is erroneous but nonnegligent and the owner must pay all the damages. One such scenario occurs when, based on the advice of the architect and engineer, the CM advises the owner to withhold payment to the contractor. It is later determined that the advice, although nonnegligent, is erroneous and caused loss to the contractor. After the contractor sues the owner and recovers in full, the owner looks in vain for reimbursement. The owner may not recover against his CM because under the AGC, AIA, and GSA PBS contracts, the CM does not warrant his advice. The owner cannot recover against the CM's surety because the bond does not cover erroneous professional advice. The owner cannot recover against the CM's errors and omissions carrier because the advice, although wrong, was either not negligent or was itself based upon the reasonable advice of the architect or engineer.

Even if the jurisdiction is one in which the architect or CM warrants advice (or if this was expressly included in the owner/CM or CM/architect contracts), ${ }^{102}$ the owner is not fully protected. Suppose that after the contractor recovers from the owner, the owner recovers from the CM, who in turn recovers from the architect. The architect will bear the loss because his errors and omissions policy does not cover contractually assumed liabilities such as warranted advice. If the CM becomes bankrupt, the owner can still recover from the architect because the warranties of advice flow through the CM to the owner, the third party beneficiary of

101. A survey by the American Consulting Engineers Council in 1980 found that an estimated $15 \%$ of the firms that are members of that organization have decided to "go naked." Moreover, it is becoming harder and harder for the design professional to obtain errors and omissions insurance. See Fisher, The Contract Documents From the Developer's Point of View, in Real Estate Construction CuR RENT PROBLEMS 127, 145-47 (PLI ed. 1973). For a discussion of the propriety of insurance as a device for spreading the risk of liability for a professional's negligence, see Besser, Privity. -An Obsolete Approach to the Liability of Accountants to Third Parties, 7 SeTON Hall L. Rev. 507, 534-37 (1976). This has been described as an "enterprise liability" approach, funneling down the ultimate burden until it reaches the consuming public. Id. at 534 n. 114 .

102. At the present time, there are no states in which the CMs or architects warrant the sufficiency of their advice. 
the CM/architect contract. Yet if the CM and the architect both become bankrupt, the owner bears the loss and cannot recover against any surety or carrier.

It must be questioned why the CM or architect cannot be insured for nonnegligent error. Why should the architect be protected from his negligence and not, a fortiori, his nonpreventable errors? The carrier need not insure these parties against all contractually assumed liabilities, but it would seem to be good economic policy to spread the risk of nonnegligent error throughout the industry through the use of insurance coverage. If such coverage is unavailable in the standard insurance market, the technique of self-insurance should be used and perhaps be made mandatory when the possibility of loss is remote. A law requiring such insurance could be modeled on state "financial responsibility" laws for automobiles. Some local agencies have already required that before construction begins, the architect must file a certificate of insurance with the owner. It should not be difficult to include nonnegligent error under such mandatory policies.

\section{$\mathrm{V}$ \\ Recommendations and Public Policy}

The judicial resistance to delegation of duty and allocation of risk presents a barrier to obtaining the benefits from one of the fastest growing and most innovative construction ideas in recent years-construction management. A redefining of the roles is consonant with the public policy of distributing risks throughout the enterprise of construction.

The owner should be held responsible only for matters within his control, such as site information, site access, and payment. Courts should continue to imply duties to not actively interfere with the performance of work and to use reasonable care in the selection of the CM. ${ }^{103}$

In delegating the duty of coordination to the CM, the owner should be relieved of liability for delays in the construction process. Some concern may arise that this result might lead to less vigilant coordination and a resulting inefficiency in the work's progress. It should be recognized, however, that the modern-day owner is not in the best position to coordinate the construction work anyway. First, the owner lacks the construction knowledge and expertise to coordinate the work effectively. Furthermore, few nonprofessional owners have the time to exercise the personal supervision over the work essential to proper coordination. Therefore, a shift of the duty would result in more efficient coordination. Should, however, the owner intervene and begin to exercise control over the progress of the work, he would be held liable for damages caused by his active interference.

The CM should have the responsibility in the contract for scheduling, coordination, and timely completion of the work. As a professional, the CM should be liable for any negligent errors or omissions in the performance of his work. The $\mathrm{CM}$, in assuming the responsibility for coordination of the job, would be exposed to the greatest liability. The owner could sue directly on his contract with the $\mathrm{CM}$, while the prime contractors could sue the CM on a third party beneficiary

103. See, e.g., Natkin \& Co. v. George A. Fuller \& Co., 437 F. Supp. 17 (W.D. Mo. 1972). 
theory. Thus, the CM would have the greatest incentive to perform his job well. This result, in turn, would serve the interests of both the owner and the prime contractors. It would remove the anticipation of litigation which may lead each party to protect his own interest at the expense of the earliest completion of the job. Moreover, the CM's professional perspective would lend a certain detachment that would inure to the benefit of all the parties.

With the CM having effectively taken over coordination, the architect could return to the duties in which he is most skilled-those involving design. The architect should be held to the standard of due care applicable to any professional.

However, if allocation of risk among the parties is to succeed, traditional means of risk shifting must be brought into line simultaneously. The CM cannot bear the potential exposure to extensive litigation which will necessarily result without protection by insurance carriers. Premiums could be shared by all the parties as costs of doing business. Any attempt to spread the risk to which the owner is exposed will fail in the absence of proper professional insurance taken by the architect, engineer, and CM. In the 1980's, however, many construction professionals do not carry malpractice insurance because they deem it inordinately expensive. With the tremendous rise in the use of the construction management method, exposure to liability is bound to increase dramatically. Thus insurance coverage (without myriad exceptions to weaken its effectiveness) becomes even more vital.

The expansion of errors and omissions coverage to include nonnegligent error would be a progressive step in terms of public policy. Since such an error, by definition, cannot be avoided even with the exercise of due care, forcing one party to bear the loss is inefficient and inequitable. Allowing the parties to spread the risk of unavoidable error reduces the cost of construction in the long run.

Much can be written on the advantages of requiring a performance and payment bond from a surety. The shifting of the risk to the surety assures completion of the contract or defrayal of the owner's costs within the bond penalty, thus allowing the owner to fix his cost at the contract price. These bonds also assure compliance with the plans and specifications, thus affording protection against defective workmanship and materials. Each state should enact the two-bond system for the protection of all the parties. Beneficiaries of the bond should be restricted to the named obligees and third party beneficiaries should not be implied in violation of the parties' expectations.

To facilitate enforcement of his duty to coordinate, the CM should be able to become a second obligee on the performance bond of the contractor. This could be accomplished by including in the price of the bond the additional cost of an extra obligee.

There should be no reason to fear the extension of performance bond protection to the owner to cover all of the contractor's liability, eliminating a per se discharge of the surety due to actions of the owner. The performance bond should cease to become coextensive with the liability of the contractor only when the owner has acted in a way prejudicial to the surety's security. Both the surety and the owner would then receive maximum protection of their interests. 


\section{VI}

\section{CONCLUSION}

The main practical advantage of the construction management approach is that a single party answerable only to the owner is responsible for the timely completion of the entire project within budget and in accordance with the plans and specifications. However, the courts in their interpretation of construction management agreements and the other contracts involved have either not perceived or not accepted the legal implications of this significant shifting of duties. Thus, the primary disadvantage of the construction management approach today is that as yet it is not well nor uniformly defined. A project-by-project education process is necessary to inform all the actors as to each one's duties and liabilities in this new arrangement. To the extent all possible problems are not anticipated and agreed upon in writing in advance, there is little direct legal precedent to aid in the resolution of disputes. While analogies may be made to traditional areas of the law, they are often made in a most tortuous manner. Thus, all parties should be encouraged, while drawing up contracts, to anticipate the legal problems outlined herein. By doing so, they may avoid being placed at the mercy of courts which may not understand today's changing relationships in the construction industry. 
